\title{
CHTĚJÍ LIDÉ SKUTEČNĚ VĚDĚT VÍCE?
}

\section{Vojtěch Kotrba ${ }^{a}$}

\section{Cass R. Sunstein: Too Much Information: Understanding What You Don't Want to Know.}

Cambridge: MIT Press, 2020. 264 stran. ISBN 978-0262044165

Profesor Cass R. Sunstein přichází s novou knihou zabývající se problematikou informací s názvem Too Much Information: Understanding What You Don 't Want to Know. Společně s ním se na knize podílejí George Loewenstein a Russel Golman (kapitola 3), Oren Bar-Gill a David Schkade (kapitola 4), a Eric Posner (kapitola 5). Profesor Sunstein je americký právník a behaviorální ekonom, který v současné době působí na Harvardské právnické fakultě. Je zakladatelem a ředitelem Programu behaviorální ekonomie a veřejné politiky právě na této fakultě. V minulosti působil např́íklad i na Právnické fakultě univerzity v Chicagu. Dále je bývalým vedoucím pracovníkem amerického Úřadu pro záležitosti informací a regulace (OIRA) z kabinetu Baracka Obamy, kde působil v letech 2009-2012, a současným členem kabinetu Joe Bidena. Zároveň je jako autor velmi aktivní. Mezi jeho knižní díla patří například Simpler: The Future of Government (2013), The Ethics of Influence (2015), \#Republic (2017), Impeachment: A Citizen's Guide (2017), The CostBenefit Revolution (2018), On Freedom (2019), Conformity (2019) nebo How Change Happens (2019). V českém překladu vyšla jeho společná kniha s držitelem Nobelovy ceny za ekonomii Richardem H. Thalerem Nudge (Št’ouch): Jak postrčit lidi k lepšimu rozhodování o zdraví, majetku a štěstí (2010, v originále 2008).

Předkládaná kniha přináší v sedmi číslovaných kapitolách přehled o problematice získávání a sdělování informací, a to primárně ve směru od státu $\mathrm{k}$ jeho obyvatelům a naopak. Co se týče prvního zmíněného směru, autor poukazuje na postoj, který mnohé vlády v minulosti i v současnosti zaujímají, a to, že víc informací umožní spotřebiteli lepší podmínky pro rozhodování. Zároveň je zastánci maximalizace informací zdůrazňováno, že spotřebitel má takzvaně ,,právo vědět“،. Autor hned v úvodu poukazuje, že současný stav vědění tomuto tradičnímu ekonomickému pohledu spíše odporuje. Spotřebitel, který

a Vysoká škola ekonomická v Praze, Národohospodářská fakulta, Česká republika

E-mail: vojtech.kotrba@vse.cz 
je zavalen informacemi, není schopný je zpracovat, a bud' je ve svém rozhodování nezohledňuje, nebo odkládá své rozhodnutí na později. Lze však poznamenat, že filozofické otázce „práva vědět“ by se autor mohl věnovat více a tento směr rozvést. Pokud by byly postoje státu ve shodě s myšlenkou utilitarismu, tedy maximalizace blahobytu ve společnosti, pak lze autorův závěr na základě empirické literatury podpořit.

Co se týče druhého zmíněného směru, autor zastává tezi, že současné vlády chtějí po svých obyvatelích vědět př́lišs. Toto tvrzení má dvě roviny, kdy první je zbytečnost získávání informací, které nejsou pro státní instituce k ničemu potřebné, a jde tak o zbytečně vynaložené úsilí na obou stranách. Zde by však autor mohl více zvážit zefektivnění použití dat o občanech ve státním rozhodování. Příklad by si stát mohl brát ze soukromých firem, které umí využívat tato data často výjimečně dobře. Druhou rovinou je pak enormní papírování, které musí mnoho obyvatel absolvovat, aby mohli např́ílad zažádat o dávku, na kterou mají podle zákona nárok. Pro tento fenomén používá autor výraz sludge, což lze volně přeložit jako bahno. Brodění se tímto bahnem následně odradí mnoho lidí od snahy vůbec jednat s veřejným sektorem.

V první kapitole autor představuje pohled na problematiku informací, který je pak nadále používán v následujících kapitolách 2-7. Autor ukazuje, proč některé informace lidé chtějí získat, proč jsou k některým indiferentní a proč některé získat nechtějí. Informace mohou přinášet jedinci dvě prospěšné hodnoty. První hodnotou je dobrý pocit. Lidé se po zjištění informace mohou cítit lépe. Př́kladem může být informace o negativním výsledku testu na COVID-19. Druhou hodnotou je instrumentální užitečnost, tedy možnost použití informace pro zlepšení vlastního života. Do této kategorie mohou např́klad spadat informace týkající se kalorických hodnot potravin. Autor v této souvislosti uvádí historku ze svého života, kdy se $\mathrm{v}$ rámci své práce $\mathrm{v}$ kabinetu Baracka Obamy podílel na zavedení povinného zveřejňování kalorických hodnot v různých typech pohostinství, například v občerstvení v kinech. Když o svém úspěchu informoval kolegu, ten mu odpověděl: „Cass zničil popcorn“ (v originále „Cass ruined popcorn“). To ukazuje, že někteří lidé zkrátka nechtějí být informováni o vysokých kalorických hodnotách některých potravin, aby si mohli jejich konzumaci naplno užít. Po obdržení patřičné informace se cítí hưr̆, ale existuje alespoň možnost, že ji použijí pro zlepšení svého budoucího zdraví. V tomto směru by také byla možná ještě obsáhlejší diskuse a možný výzkum, který by měl za cíl ukázat, zda jsou lidé schopní využít nepř́ijemných informací pro zlepšení svého života $\mathrm{v}$ delším časovém horizontu.

V závěru kapitoly autor představuje svůj průzkum, kdy se respondentů ptá, co by chtěli a nechtěli vědět a kolik by byli ochotní za informaci zaplatit. Výsledky ukazují, že mnoho spotřebitelů nemá zájem o potenciálně relevantní informace, které by mohli použít pro zlepšení svého života. Např́ílad 71 \% respondentů by chtělo vědět, zda je život na jiných planetách, ale jen $53 \%$ by chtělo vědět, zda onemocní rakovinou. Jen $27 \%$ 
respondentů by chtělo znát pravděpodobný rok svého úmrtí a $56 \%$ by chtělo znát veškeré podmínky a poplatky spojené s jejich kreditní kartou. Zajímavým faktem je, že pouze $54 \%$ respondentů by chtělo znát stav burzy cenných papírů v následujícím roce, což je informace, kterou by bylo možné snadno zpeněžit.

Předkládané výsledky autora přinášejí jistě zajímavý pohled na projevený zájem o informace. Autor však opomíjí možnost, že by stát lidi v tomto směru vzdělával a ukazoval jim, jak mohou informace lépe využít, aby mohli pozitivně ovlivnit svůj život.

Ve druhé kapitole autor řeší problematiku zvyšování blahobytu za pomoci povinných varování na informačních štítcích. V tomto směru je důležité zvážit, co mohou lidé $\mathrm{s}$ informací udělat. Některé informace nemusí souviset s rozhodováním konkrétních lidí, a nemohou je tedy využít. Jiné informace mohou být zas natolik komplikované, že jim lidé nerozumí. Takové informace přinášejí státu pouze náklady spojené se zavedením regulace a distribucí a nepřinášejí žádný prospěch. $V$ tomto směru je opět důležité zvážit, zda může povinný informační štítek alespoň zvýšit dobrý pocit jedince. Mnoho lidí může chtít např́íklad kupovat fair-trade výrobky a bude jim to přinášet dodatečné uspokojení.

Kritickou myšlenkou této kapitoly je požadavek, aby vláda vždy zvažovala náklady a výnosy zavedené regulace, což současné vlády ne vždy dělají. To autor ukazuje právě na príkladu americké vlády. To neznamená, že by autor zastával myšlenku, že není možné zavádět regulace, které po analýze nákladů a př́nosů (cost-benefit analýza) skončí v minusu, je však nutné si tento fakt uvědomovat. Tuto autorovu myšlenku lze z pohledu ekonomie považovat za zásadní. Při vynakládání finančních prostředkủ státu na regulace by měly být zvažovány plusy a minusy takovýchto kroků, což současné vlády mnohdy opomíjejí. Jsou-li regulace zaváděny pouze na základě dobrého pocitu, může docházet k velkému plýtvání zdroji. Tato myšlenka je ještě důležitější, vezme-li se v úvahu fakt, že autor je aktivně činný v politické sféře a má tak možnost př́ípadné regulace ovlivňovat.

Ve třetí kapitole se autor zabývá využitím poznatků psychologie při sdělování informací. Výzkum v této oblasti ukazuje, že lidé nemusí být schopni věnovat dostatečnou pozornost varovným štítkům, které je tedy potřeba upravit tak, aby plnily zamýšlený efekt. Zásadní v tomto směru je jednoduchost. Sdělení, která jsou jasná a jednoduchá, mají vy̌šší pravděpodobnost, že budou sloužit svému účelu. Další možnou strategií je porovnání se srovnatelnými výrobky v dané kategorii, kdy lidé mohou u dvou podobných výrobků upřednostnit ten zdravější nebo šetrnější k životnímu prostředí.

Je-li cílem právě snižení znečištění životního prostředí, pak výzkum z oblasti psychologie doporučuje porovnání. Vidí-li spotřebitel, pro kterého je životní prostředí pozitivní hodnotou, že jedna firma znečišt'uje prostředí více než druhá, může volit výrobky druhé firmy. První firma pak může být tímto způsobem motivována ke snížení vlastního znečištování. 
To samé ale platí i pro samotné občany. Př́íkladem může být placení daní, což je ve Spojených státech velké téma. Psychologický výzkum v tomto směru ukazuje, že popisné porovnávací tvrzení má vyšší účinnost než tvrzení odsuzující špatné chování. Sdělení „95\% lidí platí své daně včas“ má vyšší naději na pozitivní odezvu než sdělení „95\% si myslí, že by lidé měli platit daně včas“.

Celkově lze snahu o zohlednění poznatků z psychologie považovat za rozumnou, o čemž svědčí i rostoucí zájem ekonomů o oblast behaviorální ekonomie. I v tomto směru by mohla být více zdůrazněna důležitost cost-benefit analýzy a cen.

Čtvrtá kapitola rozvádí problematiku toho, zda si lidé ze sdělení odnesou skutečně to, co jim informující chtěl sdělit. To se typicky může týkat varování, že výrobek obsahuje některou spotřebiteli neznámou látku nebo, že je potravina geneticky modifikovaná. Obě tato varování nemusí tvrdit, že je potravina zdravotně závadná, je to však nejčastější myšlenka, kterou si spotřebitel po přečtení takového štítku odnese. Je tedy možné, že podobná varování budou způsobovat vyšší nerovnováhu na trzích a vzdalovat je od jejich optima. Regulátor by měl dobře zvážit, čeho chce svým nařízením dosáhnout a podle toho opatrně formulovat prípadná sdělení.

V této kapitole se autor dopouští mírné kontroverze se suverenitou spotřebitele, což však lze očekávat vzhledem $\mathrm{k}$ jeho myšlenkovému ukotvení v libertariánském paternalismu.

Pátá kapitola se týká morálních aspektů při koupi výrobků a regulace sdělování informací, jako je zacházení se zviŕaty chovanými pro maso, nebo zda minerály použité ve výrobku pocházejí ze země, kde jsou porušována základní lidská práva. Dalším př́ikladem může být sdělení, že k výrobě produktu mohla být využívána dětská práce. Tato sdělení neinformují spotřebitele o vlastnostech výrobku, které ovlivní jeho samotné užití, ale dávají spotřebiteli možnost projevit své preference ohledně ochrany zviŕăat nebo práv osob v jiných státech.

Zde je autor ve shodě s hlavním ekonomickým proudem a ukazuje, že přesnějšś informace o výrobku umožní spotřebiteli výběr, který je v lepší shodě s jeho preferencemi, přsstože se doplňující informace netýká př́ímých vlastností výrobku.

Šestá kapitola pojednává o sociálních sítích jakožto informačnímu fenoménu posledních let. V současné době mnoho lidí využívá sociální sítě, typicky Facebook, jako jeden z hlavních zdrojů informací. Sociální sítě však mají zajímavé charakteristiky, které je dobré si uvědomit. V první řadě si sociální sítě nekladou za cíl objektivní sdělování informací ze všech názorových proudů, aby si člověk mohl vytvořit nezaujatý názor. Naopak algoritmus Facebooku lidem nabízí informace, které odpovídají jejich vlastnímu názoru. Minulý výzkum tedy logicky ukazuje, že využívání sociálních sítí prohlubuje např́iklad radikalizaci směrem k oblíbené politické straně. 
Sociální sítě jsou zpravidla zdarma. Autor si však klade otázku, jakou hodnotu pro spotřebitele skutečně mají. Za tímto cílem sestavuje dotazník, kdy se respondentů ptá, kolik by byli ochotní platit měsíčně za využívání Facebooku. Výsledky ukazují, že medián je 5 dolarů a průměr 16,99 dolarů. Zajímavý je však i navazující dotazník, kdy je dotaz formulován jinak. Autor se ptá respondentů, kolik by požadovali zaplatit, aby na měsíc Facebook nevyužívali. Výsledky ukazují, že medián je 87,5 dolarů a průměr 89,17 dolarů. V prvním případě autor vyšetřuje ochotu zaplatit (willingness to pay), která by měla odpovídat maximální ceně. Ve druhém případě autor vyšetřuje ochotu přijmout (willingness to accept). Z pohledu tradiční ekonomie by tyto částky měly být stejné, avšak aplikovaný výzkum ukazuje, že se v mnoha př́ípadech liší. V behaviorální ekonomii se obdobná problematika řeší u takzvaného majetnického efektu (endowment effect), kdy se ukazuje, že si lidé více váží věcí, které vlastní, než věcí, které vlastnit mohou. Velké rozdíly mezi ochotou zaplatit a přijmout se ukazují u požadavků na částku nutnou zaplatit za povolení vykácet stromy v parku a zabránění vykácení těchto stromů. Za povolení ke kácení by respondenti požadovali pětkrát více. U sociálních sítí je však rozdíl mezi ochotou zaplatit a přijmout ještě vyšší. V obou prŕpadech může být tento rozdíl způsoben morálním rozhořčením. Lidé nejsou ochotni nechat ničit životní prostředí. Už pouhá myšlenka zvyšuje částku nutnou k souhlasu. Podobné to může být u sociálních sítí, u kterých jsou lidé zvyklí, že jsou zdarma.

Tato kapitola je $\mathrm{v}$ rámci knihy zajímavým odklonem jiným směrem a vydala by na samostatnou knihu v rámci tématu informací. Autor zde však alespoň uvádí čtenáře do této problematiky.

Poslední sedmá kapitola se zabývá fenoménem byrokratického přetížení občanů ze strany státu. Autor doporučuje vládě, aby úřadům dávala konkrétní požadavky na snižování papírování uvnitř úřadu i vně vůči občanům. Předpokládá-li se, že byrokratická zátěž je zde z důvodu důkladné kontroly, aby zvažovala, zda je lepší situace, kdy žádná nepovolaná osoba nezíská dávku, ale papírování zastaví mnoho povolaných osob od získání dávky, nebo situace, kdy některé nepovolané osoby dávku získají, ale dostane se i k těm povolaným. Tato myšlenka nás vrací ke cost-benefit analýze, kterou by si úřady měly zpracovat, a lze ji považovat za možná nejzásadnější myšlenku knihy.

Závěrem lze říci, že kniha je zdařilým přehledem o využívání informací a poznatky $\mathrm{z}$ ní by mohly prospět $\mathrm{k}$ zefektivnění práce mnoha úřadů a veřejného sektoru jako celku. Pro každého akademického pracovníka, který se zabývá regulacemi, přináší skvělý nástroj pro orientaci v problematice. V neposlední řadě je kniha využitelná i pro soukromé firmy, které mohou získat větší vhled do reakcí spotřebitelů na různé komunikační kampaně.

Zároveň je však vhodné nezapomínat na ukotvení autorova smýšlení v oblasti libertariánského paternalismu, který v jeho díle občas přejímá prvky paternalismu jako takového. 
Přestože je libertariánský paternalismus populární v mnoha státech západního světa a má i zajímavé empiricky měřitelné výsledky pro společnost, stojí za zvážení, zda v některých oblastech není na místě projevit více důvěry v suverenitu spotřebitele. Typicky lze říct, že v často se opakujících činnostech s dostatečnou zpětnou vazbou v podobě užitku pro spotřebitele bývají lidé sami schopní dobře řídit své chování bez nutnosti vlivu regulátora.

V knize lze naopak ocenit zdůraznění vhodnosti zavedení cost-benefit analýzy ve veřejném sektoru, což by mělo mít za cíl snížení nevhodného využivání veřejných financí v nepatřičných oblastech. Kniha je napsaná veskrze jednoduchým jazykem, a lze ji tedy doporučit i zájemcům z řad široké veřejnosti. 